\title{
EFFECTS OF AGE AT TRANSPLANTING ON MORPHOLOGICAL AND YIELD ATTRIBUTES OF THREE GENOTYPES OF SCARLET EGGPLANT
}

\author{
Oladipupo Abdulazeez Yusuf DAUDU ${ }^{1 *}$, Olamide Ahmed FALUSI ${ }^{1,2}$, Abdulhakeem \\ ABUBAKAR $^{1}$, Muhammad Liman MUHAMMAD ${ }^{1}$, Amaechi Reuben ANYICHIE ${ }^{1}$ \\ ${ }^{1}$ Department of Plant Biology, Federal University of Technology, Minna \\ ${ }^{2}$ Ibrahim Babadamasi University, Lapai Niger State - Nigeria \\ ${ }^{*}$ Corresponding author. E-mail: dauduoladipupoyusuf@yahoo.com
}

Abstract: $\quad$ Three genotypes of scarlet eggplant obtained from National Agency for Conservation of Genetic Resources and Biotechnology (NACGRAB), Ibadan, Nigeria, were evaluated for the effects of transplanting ages on morphological and yield attributes at the Department of Plant Biology experimental field, Federal University of Technology, Minna, Nigeria. The experiment was set up using a randomized complete block design (RCBD) with four replicates. Standard procedures were followed when transplanting young seedlings of the various scarlet eggplant genotypes at week 3, 4, 5 and 6 after planting. The morphological parameters measured were plant height at transplanting, at maturity and at harvest, as well as number of branches and leaves at maturity. The yield parameters measured were number of fruits per plant, weight of fruits per plant, number of seeds per fruit and weight of 100 seeds per fruit for each of the week at transplanting for the selected eggplant genotypes. It was observed from the result that plants transplanted at week 3 had the highest plant height at maturity while plants transplanted at week 6 had the highest plant height in NHGB/09/128. However, plants transplanted at week 4 had significantly highest yield parameters $(\mathrm{p} \leq 0.05)$, i.e. Weight of fruit (2.44 g), Number of seeds/fruit (115.60), and Weight of 100 seeds (0.28 g). In NHGB/09/138, plants transplanted at week 4 had significantly highest plant height at maturity, plant height at harvest, number of branches per plant at maturity and number of leaves per plant at maturity (30.35 cm, $43.00 \mathrm{~cm}, 18.00$ and 36.50 respectively). Similar trend was observed in weight of fruit (2.22 g) and number of seeds/fruit (98.20). In NHGB/09/132, plants transplanted at week 3 was significantly highest for all the yield parameters such as weight of fruit (1.15 g), number of seeds/fruit (89.80), and weight of 100 seeds $(0.48 \mathrm{~g})$. Thus, in all the three genotypes, plants transplanted at various weeks performed better than those not transplanted (control). It is therefore recommended that these ages at transplant be considered to be the best time for transplanting of these eggplant genotypes.

Keywords: genotypes, morphological parameters, scarlet eggplant, transplant, yield parameters.

\section{Introduction}

Scarlet Eggplant (Solanum aethiopicum L.) belongs to the family Solanaceae, [SUNSERI \& al. 2010]. It is believed to have originated from Africa and have been domesticated from the wild relative Solanum anguivi Lam. [KUBIE, 2013]. Scarlet Eggplant is the most important solanaceous fruit crop after tomato (Solanum lycopersicum) [FRODIN, 2004]. Scarlet Eggplant is a species of nightshade grown for its edible fruit [CHEN \& al. 2001]. The plant is a vegetable with an increasing popularity all over the world [PESSARAKLI \& DRIS, 2003]. Itis also known by other names, such as the bitter tomato, Ethiopian eggplant and Ethiopian nightshade [USDA, 2015].The fruit should be harvested for consumption at a physiological non-mature stage when the seeds are still soft 
but are already developed [GAJEWSKI \& ARASIMOWICS, 2004]. Unattractive attributes in eggplant such as bitter flavour, opaque skin, and floppy flesh is related to over matured fruit of the plant [MAYNARD, 1987].

Although excessive rainfall affects both vegetative growth and flower formation, the plant is well adapted to both wet and dry season cultivation. It requires optimum day temperature of $25^{\circ} \mathrm{C}-30^{\circ} \mathrm{C}$ and an optimum night temperature of $20^{\circ} \mathrm{C}-27^{\circ} \mathrm{C}$ [NORMAN, 1992; OBENG-OFORI \& al. 2007]. A well-drained soil rich in organic manure and $\mathrm{pH}$ ranging from 5.5 to 6.5 is suitable for its production [RICE \& al.1993].

Nutritionally, eggplant contains $92.5 \%$ water, $1 \%$ protein, $0.3 \%$ fat and $6 \%$ carbohydrate. It contains 30-50\% Iron, Fibre, Potassium, Copper, Manganese and Vitamins which include Vitamins B1, B6, Folate and Niacin [HORNA \& al. 2007; OKON \& al. 2010; CHINEDU \& al. 2011]. Medicinally, the eggplant when prepared is used in the condiments and products which is used in treating different diseases and health problems [BURKILL, 1985]. A meal of eggplant has been shown to be important to patients suffering from heart disease and raised intraocular pressure (glaucoma) [HARISH\& al. 2008]. It contains nasunin, a potent antioxidant and free radical scavenger that have been proven to protect brain cell membrane fats [SABO \& DIA, 2009]. It is also known for tackling malnutrition in Africa especially amongst children less than 5 years and women of child bearing age [CHADHA \& OLUOCH, 2003]. As food, eggplants are cooked and used in the preparation of sauces for yam porridge and cocoyam especially the bitter species like Solanum melongena [ONWUKA, 2005].

In spite of all the vast economic importance, yet it is faced with some production challenges such as disease and pests. The use of transplanting (a cultural method) in the growing of eggplant would be of importance as the effect of transplanting on other related plants like pepper increased yield [CHARLES, 1998]. Transplanting is an economically and environmentally ideal alternative to seedling. Transplanting can potentially increase yield and quality, while decreasing costs, inputs and environmental impacts [VAVRINA \& ARMBESTER, 2004]. Transplanting grants a greater flexibility in avoiding weather fronts since plants need less time in the ground. Transplants, once transferred to the field grow stronger than field seeded plants because of the sturdy root system that has been developed [CHARLES, 1998]. Transplanting offers great savings in seeds cost because the quantity used in the transplanting method is significantly lower than in direct seedling [CHARLES, 1998]. The use of cultural practices like transplanting of pepper [VAVRINA \& ARMBESTER, 2004], tomatoes [CHARLES, 1998] has proven effective over time in terms of good quality and increase yield of pepper and tomatoes.

\section{Materials and methods}

Three genotypes of Solanum aethiopicum were obtained from National Agency for Conservation of Genetic Resources and Biotechnology (NACGRAB), Ibadan. The genotypes are NHGB/09/128, NHGB/09/132 and NHGB/09/138. Plastic flower pots each of $15 \mathrm{~cm}^{3}$ capacity and $40 \mathrm{~cm}$ diameter which were used to nurse the plants were labeled with the code of each genotype collected. Twenty four (24) planting bags (each of $10 \mathrm{~cm}^{3}$ capacity and $20 \mathrm{~cm}$ diameter) were labeled according to the code of each genotype into which the corresponding genotypes from the plastic flower pots were transplanted.

The experimental design was a Randomized Complete Block Design (RCBD) with 4 replications. The ages of transplant were taken from every other week from week three 
Oladipupo Abdulazeez Yusuf DAUDU \& al.

after planting. The sandy loamy soil was scoped, mixed with water to loosen it and then mixed with Cow dung. The Cow dung was mixed thoroughly until it became homogenized with the soil. The mixing was done every week for four weeks. The planting bags were filled with the mixed soil, labeled and lined a day before transplanting.

Seedlings were raised on well prepared nursery beds; after sowing, the seeds were watered periodically. The beds were mulched using sticks to provide shade so as to protect the seedlings from harsh weather conditions. Watering was carried out every other day depending on the climatic conditions. Watering, hand picking of weeds and stirring of the soil to enhance aeration were carried out regularly. Seedlings were transplanted 3 weeks, 4 weeks, 5 weeks and 6 weeks after planting. Transplanting was done early in the morning to avoid transplant shock with four replicates from each genotype.

All the morphological parameters investigated were accessed using the standard procedures of AKINYELE \& OSEKITA (2006) as well as DAUDU \& al. (2015). These parameters include: plant heights at transplanting, plant heights at maturity, plant heights at harvest, number of branches at maturity, number of leaves at maturity, number of fruits/plant at harvest, weight of fruits at harvest, number of seeds/fruit and weight of 100 seeds per week. Quantitative data obtained were pooled for analysis. Analysis of variance (ANOVA) was used to compare the various mean values. Duncan Multiple Range Test (DMRT) post hoc test was used to separate the means. All values were considered significant at $\mathrm{P}<0.05$.

\section{Results and discussion}

The result on the morphological characteristics of genotype NHGB/09/128 showedthat there is a significant difference $(\mathrm{P}<0.05)$ in plant height from different weeks. Meanwhile, the highest plant height at transplanting which is $7.38 \mathrm{~cm}$ produced by week 6 is significantly the same with week 5 but significantly different from every other week. The result on the yield of genotype NHGB/09/128 showed that the highest yield in terms of weight of fruit among the weeks is $2.44 \mathrm{~g}$ from week 5 and is significantly the same with week 3 while the lowest yield recorded in terms of weight of fruit is $1.33 \mathrm{~g}$ from week 5 which is statistically the same with week 6 (Table 1 and 2).

VAVRINA \& ARMBESTER (2004) established the need to get appropriate time in transplanting solanaceous crops to enhance optimum yield production, especially pepper. In NHGB/09/132, the analysis of variance of the result showed that there is significant difference $(\mathrm{P}<0.05)$ among the weeks in terms of height. The highest height recorded is $7.35 \mathrm{~cm}$ which was produced by week 5 and is significantly the same with week 3 , while the lowest plant height $(3.25 \mathrm{~cm})$ produced by week 4 is significantly different from all other values. The result on the yield of genotype NHGB/09/132 showed that the highest yield in terms of weight of 100 seeds among the weeks is $0.24 \mathrm{~g}$ from week 3 and is significantly different from every other week, while the lowest yield recorded is 0.22 from week 5 and week 6 which are significantly the same (Table 1 and 2).

In NHGB/09/138, the analysis of variance of the result showed that there is significant difference $(\mathrm{P}<0.05)$ among the weeks in term of plant height. However, the highest plant height at transplanting which is $8.55 \mathrm{~cm}$ produced by week 5 is significantly different from every other week. The highest yield in terms of weight of fruit among the weeks is $2.22 \mathrm{~g}$ from week 4 and is significantly different from every other week while the 
lowest yield recorded in terms of weight of fruit is $1.02 \mathrm{~g}$ from week 6 which is significantly the same with week 5 (Table 1 and 2).

The result obtained in terms of morphological and yield parameter of scarlet eggplant (Solanum aethopicum) in genotypes NHGB/09/138, NHGB/09/132 and NHGB/09/128 indicated that they were affected by various ages at transplanting. For genotype NHGB/09/128, the height at maturity with number of leaves and branches did better at week 5 and week 6 . This result is contradictory to LOU \& al. (1993) who indicated that younger eggplant grew more vigorously after transplanting and yielded greater than older seedlings in China. The yield of the same genotype at week 4 had the highest yield in terms of weight of fruit per plant, number of seeds per fruit and weight of 100 seeds. This agrees with the work of SHUKLA \& al. (2011, 2013) who reported that middle aged transplant produced more fruit than the younger or older transplants. This may be as a result of younger seedlings having less storage of food needed for vegetative growth and older transplants too mature, which might have limited vegetative growth, thereby producing non-vigorous plants having low yield and poor quality seeds. The older seedlings might have almost reached their flowering stage before been transplanted, this will definitely hinder higher fruit or heavier fruit production. Similar assertion had been made by SHUKLA \& al. (2013). However, this result is in contrary to that of HOTTA \& al. (1993) in Japan who determined that eggplant seedlings transplanted at 40 day after sowing were the most successful in summer trials which might be due to difference in planting periods and different genetic makeup of the plants. For genotype NHGB/09/132, the morphological parameters yielded better in week 3 and the result is in agreement with LOU \& al. (1993) who indicated that younger eggplant grew more vigorously after transplanting and yielded greater than older seedlings in China.

The yield of genotype NHGB/09/132, in term of weight of fruit per plant, number of seeds per fruit and weight of 100 seeds, contradicts HARMON \& al. (1991) who indicated week 6 and 7 eggplant grew more vigorously after transplanting. For genotype NHGB/09/138, the morphological parameters did better at week 4 which is also in contrary to the findings of HOTTA \& al. (1993) who opined that transplant at week 40 days grew more vigorously than other weeks and the yield also did better in week 4 . This result contradicts HARMON \& al. (1991) who opined that older weeks did better that the earlier weeks. For all the genotypes in terms of plant yield, week 3 and week 4 transplants tend to have the highest degree of yield; similar report has also been reported by AKINROTIMI \& ANIEKWE (2018) in green pepper.

Table 1. Agro-morphological parameters of the eggplant genotypes at different week intervals.

\begin{tabular}{|c|c|c|c|c|c|}
\hline \multirow{2}{*}{$\begin{array}{l}\text { Age of } \\
\text { plants }\end{array}$} & \multicolumn{3}{|c|}{ Heights (cm) } & \multicolumn{2}{|c|}{ Morphology at maturity } \\
\hline & Transplanting & Maturity & Harvest & Branches & Leaves \\
\hline \multicolumn{6}{|c|}{ NHGB/09/128 } \\
\hline WEEK 3 & $5.48 \pm 0.23^{b}$ & $15.90 \pm 0.65^{b}$ & $29.00 \pm 1.00^{\mathrm{a}}$ & $8.50 \pm 0.50^{\mathrm{a}}$ & $17.00 \pm 4.50^{\mathrm{a}}$ \\
\hline WEEK 4 & $4.78 \pm 0.23^{b}$ & $14.75 \pm 3.00^{\mathrm{b}}$ & $38.00 \pm 1.00^{b}$ & $12.00 \pm 1.00^{\mathrm{a}}$ & $26.75 \pm 2.75^{a}$ \\
\hline WEEK 5 & $6.85 \pm 0.10^{c}$ & $15.00 \pm 0.00^{\mathrm{b}}$ & $50.50 \pm 1.50^{\mathrm{c}}$ & $14.50 \pm 0.00^{\mathrm{a}}$ & $27.00 \pm 0.00^{\mathrm{a}}$ \\
\hline WEEK 6 & $7.38 \pm 0.63^{c}$ & $11.00 \pm 1.00^{\mathrm{ab}}$ & $58.00 \pm 3.00^{d}$ & $12.00 \pm 0.00^{\mathrm{a}}$ & $18.75 \pm 0.75^{a}$ \\
\hline CONTROL & $0.00 \pm 0.00^{\mathrm{a}}$ & $8.50 \pm 0.50^{\mathrm{a}}$ & $31.00 \pm 1.00^{\mathrm{a}}$ & $11.50 \pm 0.50^{a}$ & $12.00 \pm 0.00^{a}$ \\
\hline \multicolumn{6}{|c|}{ NHGB/09/132 } \\
\hline WEEK 3 & $3.70 \pm 0.25^{b}$ & $12.33 \pm 1.33^{\mathrm{a}}$ & $27.38 \pm 0.88^{\mathrm{a}}$ & $12.08 \pm 1.58^{\mathrm{b}}$ & $31.25 \pm 1.25^{b}$ \\
\hline WEEK 4 & $3.25 \pm 0.75^{b}$ & $25.13 \pm 5.63^{b}$ & $31.25 \pm 1.25^{\mathrm{a}}$ & $20.00 \pm 0.50^{c}$ & $61.75 \pm 8.75^{c}$ \\
\hline WEEK 5 & $7.35 \pm 0.50^{c}$ & $14.75 \pm 0.75^{\mathrm{a}}$ & $38.25 \pm 0.75^{b}$ & $14.25 \pm 1.25^{b}$ & $40.25 \pm 0.75^{b}$ \\
\hline
\end{tabular}


Oladipupo Abdulazeez Yusuf DAUDU \& al.

\begin{tabular}{|l|l|l|l|l|l|}
\hline WEEK 6 & $6.70 \pm 1.30^{\mathrm{c}}$ & $13.00 \pm 1.00^{\mathrm{a}}$ & $43.25 \pm 1.75^{\mathrm{c}}$ & $6.25 \pm 0.25^{\mathrm{a}}$ & $15.00 \pm 1.00^{\mathrm{a}}$ \\
\hline CONTROL & $0.00 \pm 0.00^{\mathrm{a}}$ & $12.00 \pm 0.00^{\mathrm{a}}$ & $29.00 \pm 1.00^{\mathrm{a}}$ & $5.00 \pm 1.00^{\mathrm{a}}$ & $10.50 \pm 0.50^{\mathrm{a}}$ \\
\hline Total & $4.20 \pm 0.91$ & $15.44 \pm 1.87$ & $33.83 \pm 2.04$ & $11.52 \pm 1.86$ & $31.75 \pm 6.30$ \\
\hline \multicolumn{7}{|c|}{ NHGB/09/138 } \\
\hline WEEK 3 & $5.30 \pm 0.20^{\mathrm{b}}$ & $16.63 \pm 0.13^{\mathrm{a}}$ & $37.50 \pm 1.00^{\mathrm{b}}$ & $8.50 \pm 0.50^{\mathrm{ab}}$ & $13.50 \pm 1.00^{\mathrm{a}}$ \\
\hline WEEK 4 & $6.00 \pm 0.20^{\mathrm{bc}}$ & $30.35 \pm 1.65^{\mathrm{b}}$ & $43.00 \pm 1.00^{\mathrm{c}}$ & $18.00 \pm 1.50^{\mathrm{c}}$ & $36.50 \pm 4.00^{\mathrm{b}}$ \\
\hline WEEK 5 & $8.55 \pm 0.50^{\mathrm{d}}$ & $17.00 \pm 2.00^{\mathrm{a}}$ & $39.00 \pm 1.00^{\mathrm{b}}$ & $11.75 \pm 2.25^{\mathrm{b}}$ & $16.00 \pm 1.00^{\mathrm{a}}$ \\
\hline WEEK 6 & $6.65 \pm 0.15^{\mathrm{c}}$ & $14.50 \pm 0.50^{\mathrm{a}}$ & $29.00 \pm 1.00^{\mathrm{a}}$ & $8.50 \pm 1.50^{\mathrm{ab}}$ & $12.25 \pm 0.25^{\mathrm{a}}$ \\
\hline CONTROL & $0.00 \pm 0.00^{\mathrm{a}}$ & $13.50 \pm 0.50^{\mathrm{a}}$ & $41.00 \pm 3.00^{\mathrm{bc}}$ & $6.00 \pm 0.00^{\mathrm{a}}$ & $11.00 \pm 1.00^{\mathrm{a}}$ \\
\hline Total & $5.30 \pm 0.96$ & $18.40 \pm 2.08$ & $37.90 \pm 1.69$ & $10.55 \pm 1.46$ & $17.85 \pm 3.22$ \\
\hline
\end{tabular}

Values are means \pm standard error, values followed by the same superscript on the same column is not significantly different at $\mathrm{P}>0.05$ tested by DMRT.

Table 2. Yield parameters of the eggplant genotypes at different week intervals.

\begin{tabular}{|c|c|c|c|}
\hline Yield & Weight of fruit (g) & Number of seeds/fruit & Weight of 100 seeds \\
\hline & \multicolumn{3}{|c|}{ NHGB/09/128 } \\
\hline WEEK 3 & $2.34 \pm 0.17^{b}$ & $100.80 \pm 5.09^{\mathrm{ab}}$ & $0.22 \pm 0.00^{\mathrm{a}}$ \\
\hline WEEK 4 & $2.44 \pm 0.26^{\mathrm{b}}$ & $115.60 \pm 6.84^{\mathrm{b}}$ & $0.28 \pm 0.00^{c}$ \\
\hline WEEK 5 & $1.69 \pm 0.28^{\mathrm{a}}$ & $111.40 \pm 8.34^{b}$ & $0.22 \pm 0.00^{\mathrm{b}}$ \\
\hline WEEK 6 & $1.33 \pm 0.07^{\mathrm{a}}$ & $89.20 \pm 2.48^{\mathrm{a}}$ & $0.23 \pm 0.00^{\mathrm{d}}$ \\
\hline CONTROL & $1.21 \pm 0.10^{\mathrm{a}}$ & $88.15 \pm 1.38^{\mathrm{a}}$ & $0.22 \pm 0.01^{\mathrm{a}}$ \\
\hline \multirow[t]{2}{*}{ Total } & $1.95 \pm 0.14$ & $104.25 \pm 3.65$ & $0.24 \pm 0.01$ \\
\hline & \multicolumn{3}{|c|}{ NHGB/09/132 } \\
\hline WEEK 3 & $1.15 \pm 0.08^{\mathrm{b}}$ & $89.80 \pm 6.03^{b}$ & $0.48 \pm 0.01^{\mathrm{d}}$ \\
\hline WEEK 4 & $1.07 \pm 0.05^{\mathrm{b}}$ & $78.80 \pm 3.75^{\mathrm{ab}}$ & $0.46 \pm 0.01^{\mathrm{c}}$ \\
\hline WEEK 5 & $1.02 \pm 0.09^{b}$ & $62.60 \pm 7.05^{\mathrm{a}}$ & $0.44 \pm 0.00^{\mathrm{b}}$ \\
\hline WEEK 6 & $0.94 \pm 0.04^{\mathrm{b}}$ & $69.80 \pm 6.07^{\mathrm{a}}$ & $0.44 \pm 0.00^{\mathrm{b}}$ \\
\hline CONTROL & $0.62 \pm 0.03^{\mathrm{a}}$ & $60.44 \pm 3.25^{\mathrm{a}}$ & $0.34 \pm 0.00^{\mathrm{a}}$ \\
\hline \multirow[t]{2}{*}{ Total } & $0.96 \pm 0.04$ & $75.25 \pm 3.56$ & $0.46 \pm 0.00$ \\
\hline & \multicolumn{3}{|c|}{ NHGB/09/138 } \\
\hline WEEK 3 & $1.53 \pm 0.10^{\mathrm{b}}$ & $83.80 \pm 2.71^{\mathrm{ab}}$ & $0.23 \pm 0.00^{\mathrm{a}}$ \\
\hline WEEK 4 & $2.22 \pm 0.04^{c}$ & $98.20 \pm 5.27^{b}$ & $0.22 \pm 0.01^{\mathrm{a}}$ \\
\hline WEEK 5 & $1.10 \pm 0.08^{a}$ & $64.20 \pm 11.91^{\mathrm{a}}$ & $0.22 \pm 0.00^{\mathrm{a}}$ \\
\hline WEEK 6 & $1.02 \pm 0.15^{\mathrm{a}}$ & $96.60 \pm 3.12^{b}$ & $0.30 \pm 0.00^{b}$ \\
\hline CONTROL & $0.99 \pm 0.15^{\mathrm{a}}$ & $62.10 \pm 6.68^{\mathrm{a}}$ & $0.20 \pm 0.10^{\mathrm{a}}$ \\
\hline Total & $1.47 \pm 0.12$ & $85.70 \pm 4.42$ & $0.24 \pm 0.01$ \\
\hline
\end{tabular}

Values are means \pm standard error, values followed by the same superscript on the same column is not significantly different at $\mathrm{P}>0.05$ tested by DMRT.

\section{Conclusion}

It is therefore concluded that different age at transplanting tends to enhance variations in certain morphological and yield parameters in selected scarlet eggplant genotypes in Nigeria. It was also observed that transplanting at week 3 after planting is best for optimum yield in NHGB/09/132 whereas, transplanting at week 4 after planting is the best for optimum yield attributes in NHGB/09/128 and NHGB/09/138. 


\section{Notes on contributors}

Oladipupo Abdulazeez Yusuf DAUDU - is a Plant breeder with special interest in germplasm studies of indigenous crop plants. He holds a $\mathrm{PhD}$ in applied plant genetics and breeding.

Olamide Ahmed FALUSI - is a professor of plant cytogenetics and breeding with special interest in inheritance studies of plants.

Abdulhakeem ABUBAKAR - is Plant geneticist and breeder with special interest in mutation breeding. He holds a PhD in applied plant genetics and breeding.

Muhammad Liman MUHAMMAD - is Plant geneticist and breeder with special interest in mutation breeding. He holds a PhD in applied plant genetics and breeding.

breeding.

Amaechi Reuben ANYICHIE - He is a Masters Student in applied plant genetics and

\section{Acknowledgement}

We appreciate the management of the National Agency for Conservation of Genetic Resources and Biotechnology (NACGRAB), Ibadan providing us the seeds of the various accessions used for this research.

\section{References}

AKINROTIMI C. A. \& ANIEKWE N. L. 2018. Effect of transplanting age on the growth and yield of Green Pepper (Capsicum annuum L.) in Abakaliki Southeastern agro-ecological zone of Nigeria. Agricultural Extension Journal. 2(2): 106-110.

AKINYELE B. O. \& OSEKITA O. S. 2006. Correlation and path coefficient analyses of seed yieldattributes in okra [Abelmoschus esculentus (L.) Moench]. African Journal of Biotechnology. 5(14): 1330-1336.

BURKILL H. M. 1985. The useful plants of West tropical Africa, $2^{\text {nd }}$ edition. Royal Botanic Gardens, Kew, UK. Available at https://www.feedipedia.org/node/6402. Retrieved on $19^{\text {th }}$ January, 2019.

CHADHA M. L. \& OLUOCH M. O. 2003. Home-based vegetable gardens and other strategies to overcome micronutrient malnutrition in developing countries. Food Nutrition and Agriculture. 32: 17-23.

CHARLES M. 1998. Physiological basis of UV-C induced disease resistance in post-harvest tomato fruits. PhD Thesis, Laval University Quebec, Canada.

CHEN N. C., LI H. M. \& KAIL T. 2001. Eggplant Production, AVRD, http://www.avrdc.org/LC/eggplant/ production/oltitle.html.

CHINEDU S. N., OLASUMBO A. C., EBOJI O. K., EMILOJU O. C., ARINOLA O. K. \& DANIA D. I. 2011. Proximate and phytochemical analyses of Solanum aethiopicum L. and Solanum macrocarpon L. fruits. Research Journal of Chemical Sciences. 1(3): 63-71.

DAUDU O. A. Y., FALUSI O. A., DANGANA M. C., ABUBAKAR A., YAHAYA S. A. \& ABEJIDE D. R. 2015. Collection and evaluation of Roselle (Hibiscus sabdariffa L.) germplasm in Nigeria. African Journal of Food Science. 9(3): 92-96. https://doi.org/10.5897/AJFS2014.1225

FRODIN D. G. 2004. History and concepts of big plant genera. Taxon. 53(3): $753-776$. https://doi.org/10.2307/4135449

GAJEWSKI M. \& ARASIMOWICZ D. 2004. Sensory quality of eggplant fruits (Solanum melongena L.) as affected by cultivar and maturity stage. Polish Journal of Food and Nutrition Sciences. 13(3): 249-254.

HARISH B. N., BABU P. A., MAHESH T. \& VENKATESH Y. P. 2008. A cross-sectional study on the prevalence of food allergy to eggplant. Clinical and Experimental Allergy. 38(11): 1795-1803. https://doi.org/10.1111/j.1365-2222.2008.03076.x

HARMON R., WESTON L A. \& JONES T. 1991. Effect of root cell size and transplant age on yield of transplanted eggplant. Horticultural Science. 26(6): 689 (Abstract).

HORNA D., SMALE M. \& FALCK-ZEPEDA J. 2007. Assessing the potential economic impact of genetically modified crops in Ghana: insect-resistant garden egg. International Food Policy Research Institute. Brief no. 4.

HOTTA Y., TAKAMATSU M. \& ASANO M. 1993. Improvement of forcing culture of eggplant. II. Effect of seedling age on growth and production. Research Bulletin of Aichi ken Agricultural Research Center (in Japanese). 25: 171-177.

KUBIE L. D. 2013. Evaluation of genetic diversity in garden egg (Solanum aethiopicum) germplasm in Ghana. Thesis submitted to the Department of Crop Science, University of Ghana, Legon, pp. 97.

LOU H. N., KATO T. \& TORU K. 1993. Influence of seedling age on endogenous hormones, seedling quality and productivity in eggplant. Acta Horticulturae. 20: 257-260. 
Oladipupo Abdulazeez Yusuf DAUDU \& al.

MAYNARD D. N. 1987. Vegetable variety evaluation demonstrations: A manual for county extension faculty. University of Florida Cooperation Extension Service. Circular 762: pp. 15.

NORMAN J. C. 1992. Tropical Vegetable Crops. Arthur H. Stockwell Ltd. 252 pp.

OBENG-OFORI D., DANQUAH E. Y. \& OFOSU-ANIM J. 2007. Vegetable and Spice Crop Production in WestAfrica. City Publishers. Ltd., Accra, pp: 85-93.

OKON U. E., ENETE A. A. \& BASSEY N. E. 2010. Technical efficiency and its determinants in garden egg (Solanum spp.) production in Uyo Metropolis, Akwa Ibom State. Field Actions Science Reports. The Journal of Field Actions, (Special Issue 1): 1-7.

ONWUKA G. I. 2005. Food Analysis and Instrumentation. Theory and Practices. Food Science Journal. 8(5): 335. https://doi.org/10.12691/jfnr-2-4-8

PESSARAKLI M. M. \& DRIS R. 2003. Effects of pruning and spacing on the yield and quality of eggplant. Food Agricultural and Environment. 1(2): 215-216.

RICE R. P., RICE L. W. \& TINDAL H. D. 1993. Fruits and vegetable production in Africa. The Macmillan Press Ltd. London and Basingstoke, pp. 221-230.

SABO E. \& DIA Y. Z. 2009. Awareness and effectiveness of vegetable technology. Information packages by vegetable Farmers in Adamawa State, Nigeria. Journal of Agricultural Resources. 4(2): 65-70.

SHUKLA Y. R., CHHOPAL T. \& SHARMA R. 2011. Effect of age of transplants on growth and yield of Capsicum. Journal of Farm Sciences. 1(2): 56-62. Corpus ID: 73199351

SHUKLA Y. R., THUKTAN C. \& RAJENDER S. 2013. Effect of age of transplants on fruit and seed yield of tomato (Solanum lycopersicum L.). Journal of Horticultural Science. 8(1): 99-102.

SUNSERI F., POLIGNANO G. B., ALBA V., LOTTI C., BISIGNANO V., MENNELLA G. \& RICCIARDI L. 2010. Genetic diversity and characterization of African eggplant germplasm collection. African Journal of Plant Science. 4(7): 231-241. https://doi.org/10.5897/AJPS.9000128

USDA, Natural Resources Conservation Service 2015. Solanum aethiopicum. Plants Database. Retrieved $25^{\text {th }}$ February, 2017.

VAVRINA C. S. \& ARMBRESTER K. 2004. Effect of transplant age and cell size on pepper production. SWFREC Res. Rpt. IMM. 12: 91-98.

How to cite this article:

DAUDU O. A. Y., FALUSI O. A., ABUBAKAR A., MUHAMMAD M. L. \& ANYICHIE A. R. 2020. Effects of age at transplanting on morphological and yield attributes of three genotypes of scarlet eggplant. $J$. Plant Develop. 27: 129-135. https://doi.org/10.33628/jpd.2020.27.1.129 